10. Clinical and Laboratory Standards Institute, Performance standards for antimicrobial disk susceptibility tests - Tenth edition, Approved Standard CLSI Document M2-A10, CLSI, Wayne, PA. -2009. -V. 29. -№. 1.

11. Laboratorni metody doslidzhennya u biolohiyi, tvarynnytstvi ta veterynarniy medytsyni: dovidnyk / Vlizlo V. V., Fedoruk R. S., Ratych I. B. ta in.; za red. V. V. Vlizla. - Lviv: Spolom, 2012. - 764 s. (in Ukrainian).

Рецензент - Ю. М. Косенко, д. біол. н., ДНДКІ ветпрепаратів та кормових добавок.

УДК 619:576.895.421

doi: $10.36359 /$ scivp.2019-20-2.16

\title{
ВИВЧЕННЯ ШВИДКОСТІ НАСТАННЯ СТАНУ НОКДАУН, ВИСОТИ ПІДЙОМУ ІКСОДОВИХ КЛІЩІВ ПО ОБРОБЛЕНІЙ ТКАНИНІ ПРЕПАРАТАМИ ПРОФІЛАЙН КРАПЛІ ПРОТИПАРАЗИТАРНІ ТА ПРОФІЛАЙН НАШИЙНИК ПРОТИПАРАЗИТАРНИЙ
}

\author{
C. А. Сапко, канд. вет. наук \\ ТОВ «НВП "СУЗІР'Я» \\ вул. Зернова 4, м. Харків, 61105, Україна
}

Визначено швидкість настання стану нокдауну, висота підйому кліщів по обробленій тканині препаратами ПрофіЛайн краплі протипаразитарні та ПрофіЛайн нашийник протипаразитарний. ПрофіЛайн краплі протипаразитарні містять в складі фіпроніл у комбінації з S-метопрен, ПрофіЛайн нашийник протипаразитарний - пропоксур. Препарат ПрофіЛайн краплі протипаразитарні представляють собою інсекто-акарицидний розчин, в практичних умовах застосовуються одноразово шляхом точкового нанесення на шкіру. ПрофіЛайн нашийник протипаразитарний призначений для постійного носіння твариною як профілактичний захист від ектопаразитів.

Встановлено, що препарати, які тестуються, мають виражений нокдаун-ефект, час наставання стану нокдауну складає: у препарату ПрофіЛайн краплі протипаразитарні 1,46 хв, ПрофіЛайн нашийник протипаразитарний - 2,23 хв при середній висоті підйому, відповідно 10,6 та 15,64 см.

Ключові слова: ПРОФІЛАЙН КРАПЛІ ПРОТИПАРАЗИТАРНІ, ПРОФІЛАЙН НАШИЙНИК ПРОТИПАРАЗИТАРНИЙ, ФІПРОНІЛ, ПРОПОКСУР, S-MЕТОПРЕН, НОКДАУН-ЕФЕКТ, КЛІЩ, ІНСЕКТОАКАРИЦИД.

Комахи та кліщі завдають значної шкоди здоров'ю тварин [Paliy A. P., Mashkey A. M., Sumakova N. V., Paliy A. P. (2018)]. Вони є переносниками багатьох інфекційних та інвазійних хвороб, а також викликають занепокоєння і розвиток стресу у собак і котів.

До складу препарату ПрофіЛайн краплі протипаразитарні входить фіпроніл та Sметопрен. Фіпроніл відноситься до групи фенілпіразол, що відрізняється високо тривалою інсектицидною токсичністю. Фенілпіразол - клас пестицидів, розроблений для боротьби 3 популяціями шкідників, резистентними до інших груп інсектицидів. Фіпроніл володіє 
контактно-кишковою дією, механізм якої полягає в блокуванні гамма-аміномасляної кислоти (ГАМК), яка регулює проходження нервового імпульсу через хлор-іонні канали в мембранах нервових клітин [Davey R. B., Ahrens E. H., George J. E., Hunter J. S., Jeannin P. (2001); Sirisoma N. S., Ratra G. S., Tomizawa M., Casida J. E, (2001)]. Другою складовою даного препарату є Sметопрен, який порушує синтез хітину i, тим самим, порушує розвиток блох на стадіях яйця, личинки та лялечки, тому запобігає появі статевозрілих комах на тваринах та в місцях їх утримання [Дж. Пиментел, Дж. Кунрод. (1992)].

До складу препарату ПрофіЛайн нашийник протипаразитарний входить пропоксур, який є найбільш поширеною діючою речовиною класу карбамати. Карбамати (або похідні карбамінової кислоти) - складні ефіри карбамінової кислоти, які отримали широке застосування в сільському господарстві. Пропоксур має II клас небезпеки, тобто помірно небезпечний. Препарат проявляє високу ефективність відносно паразитичних комах, а також проявляє репелентну дію [Kovacic P., Somanathan R. (2012)]. Пропоксур діє швидко і гнітюче на кліща, вже через 3-5 хв порушуючи координацію і викликаючи хаотичні переміщення, а не цілеспрямований пошук місця укусу, але вбиває повільно, або тільки викликає параліч [Мельников Н. Н. (1987)].

Метою наших досліджень було вивчення швидкості настання стану нокдаун та висоти підйому кліщів по обробленій тканині препаратами ПрофіЛайн краплі протипаразитарні та ПрофіЛайн нашийник протипаразитарний (розчин для просочування).

Матеріали і методи. У дослідженнях були використані ветеринарні препарати: ПрофіЛайн краплі протипаразитарні, який містить 10,0 \% фіпронілу, 10,0 \% S-метопрену, та розчин для просочування стрічки ПрофіЛайн нашийник проти паразитарний, у складі якого $€$ 1,5 г пропоксуру у 10 мл.

Швидкість настання стану нокдауну та висоти підйому кліщів по обробленій тканині вивчали наступним чином. Підготували 3 тести (2 для кожного препарату і 1 контрольний): на стрічках з бавовняної бязі розміром $10 \times 70$ см олівцем наносили позначки довжиною від 0 до 60 см, причому першу (нульову) позначку робили на відстані 10 см від краю. На ділянки стрічок, розміщених горизонтально на невсмоктуючі поверхні (скло), починаючи від позначки 0 до 10, з піпетки рівномірно наносили кожний препарат. Контрольний тест обробляли аналогічно, використовуючи ізопропіловий спирт (розчинник, що входить до складу препаратів). Після випаровування розчинника (приблизно 60 хв) тести розвішували в однакових контрольованих умовах температури, вологості і освітленості. Досліди проводили в день обробки. Тести закріплювали під кутом 70 градусів. Кліщів по одному поміщали на 5 см нижче нульової позначки і спостерігали за їх пересуванням вгору по тканині, додатково стимулюючи їх пальцем спостерігача, який тримали на відстані 0,5 см від гіпостома кліща. За допомогою секундоміра реєстрували час від моменту перетину кліщем нижньої межі обробленої ділянки до відокремлення його $з$ тесту, що відповідає часу настання стану нокдауну (T, хвилин). За відпалими паразитами вели подальше спостереження. Досвід проводили з 70 кліщами, 10 для кожної групи. Розраховували середнє значення часу настання стану нокдауну (Тср.) в хвилинах. Одночасно з визначенням Тср. реєстрували максимальну висоту підйому кліща по тесту $(\mathrm{H}, \mathrm{cm})$ і також розраховували середнє значення показника Нср. в сантиметрах [Арисов М. В., Архипов И. А., (2018)].

Дослідження проводили у квітні-червні 2019 р. Збір кліщів проводили загальноприйнятою методикою на «прапор», або «волокушу». [Gazzavi-Rogozina L., Tkachov O., Filiptsova O., Naboka O., Burlaka I., Dyomina Y., \& Pidgaina V. (2018)]. Збір кліщів проводили у трьох районах міста Харкова: Московський район (Парк культури та відпочинку Перемога), Шевченківський район (Олексіївський лугопарк), Холодногірський район (Парк Юність).

Результати й обговорення. Результати проведених тестів наведені в таблиці. 
Результати визначення швидкості настання стану нокдауну і висоти підйому кліщів по обробленій тканині препаратами ПрофіЛайн краплі протипаразитарні та ПрофіЛайн нашийник протипаразитарний

\begin{tabular}{|c|c|c|c|c|c|c|c|}
\hline \multirow{2}{*}{ Групи } & \multirow{2}{*}{ № ח/ח } & \multicolumn{3}{|c|}{ ПрофіЛайн нашийник протипаразитарний } & \multicolumn{3}{|c|}{ ПрофіЛайн краплі проти паразитарні } \\
\hline & & Т10. сек & H. cM & Тн. Хв & Т10. сек & H. $\mathrm{cm}$ & Тн. Хв. \\
\hline \multirow{10}{*}{ 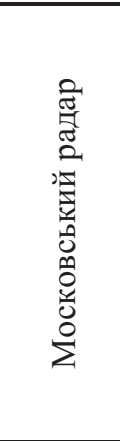 } & 1 & 47 & 18.2 & 3.55 & 56 & 9.4 & 0.58 \\
\hline & 2 & 38 & 9.3 & 1.51 & 51 & 8.1 & 0.54 \\
\hline & 3 & 32 & 11.2 & 2.15 & 52 & 10.2 & 2.24 \\
\hline & 4 & 37 & 10.5 & 2.1 & 48 & 10.1 & 1.57 \\
\hline & 5 & 42 & 19.4 & 5.1 & 52 & 8.9 & 1 \\
\hline & 6 & 50 & 8.4 & 0.54 & 54 & 9.9 & 1.15 \\
\hline & 7 & 38 & 14.3 & 3.45 & 47 & 10.5 & 1.1 \\
\hline & 8 & 48 & 12.1 & 1.44 & 46 & 10.1 & 1.25 \\
\hline & 9 & 52 & 9.8 & 1.5 & 49 & 8.4 & 0.5 \\
\hline & 10 & 42 & 10.4 & 2 & 39 & 12.6 & 2.5 \\
\hline \multicolumn{2}{|c|}{ Середнє у групі } & $42.6 \pm 6,48$ & $12.36 \pm 3,77$ & $2.33 \pm 1,33$ & $49.4 \pm 4,81$ & $9.82 \pm 1,27$ & $1.24 \pm 0,69$ \\
\hline \multirow{10}{*}{ 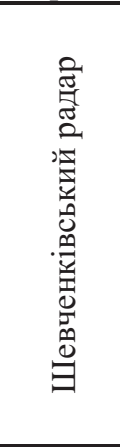 } & 1 & 41 & 7.1 & 1.08 & 39 & 12.4 & 1.58 \\
\hline & 2 & 52 & 8.3 & 1.14 & 41 & 11.2 & 2.04 \\
\hline & 3 & 46 & 11.8 & 2.44 & 58 & 10.4 & 1.15 \\
\hline & 4 & 45 & 13.4 & 2.15 & 52 & 10.2 & 1.24 \\
\hline & 5 & 52 & 14.1 & 1.58 & 59 & 11.1 & 2.3 \\
\hline & 6 & 38 & 12.9 & 2 & 45 & 12.2 & 2.45 \\
\hline & 7 & 41 & 13.4 & 2.36 & 39 & 10.4 & 1.54 \\
\hline & 8 & 37 & 18.1 & 3.2 & 47 & 11.8 & 2.05 \\
\hline & 9 & 45 & 15.4 & 2.44 & 54 & 8.5 & 0.55 \\
\hline & 10 & 30 & 25.1 & 4.51 & 38 & 12.4 & 1.55 \\
\hline \multicolumn{2}{|c|}{ Середнє у групі } & $42.7 \pm 6,79$ & $13.96 \pm 5,04$ & $2.29 \pm 1,01$ & $47.2 \pm 8,08$ & $11.06 \pm 1,23$ & $1.64 \pm 0,58$ \\
\hline \multirow{10}{*}{ 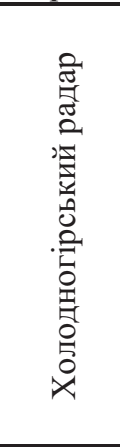 } & 1 & 32 & 17 & 2.25 & 38 & 12.6 & 1.24 \\
\hline & 2 & 34 & 26 & 2.35 & 42 & 10.1 & 0.58 \\
\hline & 3 & 31 & 21 & 1.45 & 52 & 9.8 & 0.57 \\
\hline & 4 & 42 & 16 & 2.3 & 43 & 11.3 & 1.36 \\
\hline & 5 & 52 & 15 & 2.05 & 47 & 11.4 & 2.14 \\
\hline & 6 & 30 & 23 & 2.1 & 38 & 13.5 & 3.54 \\
\hline & 7 & 29 & 25 & 2.15 & 41 & 10.4 & 1.45 \\
\hline & 8 & 33 & 20 & 2.47 & 54 & 8.5 & 0.58 \\
\hline & 9 & 31 & 24 & 2.18 & 58 & 8.8 & 1.1 \\
\hline & 10 & 34 & 19 & 1.58 & 43 & 12.8 & 2.48 \\
\hline \multicolumn{2}{|c|}{ Середнє у групі } & $34.8 \pm 7,03$ & $20.6 \pm 3,86$ & $2.08 \pm 0,33$ & $45.6 \pm 6,91$ & $10.92 \pm 1,69$ & $1.50 \pm 0,96$ \\
\hline \multicolumn{2}{|c|}{ Середнє } & $40.03 \pm 4,53$ & $15.64 \pm 4,37$ & $2.23 \pm 0,13$ & $47.4 \pm 1,91$ & $10.6 \pm 0,68$ & $1.46 \pm 0,2$ \\
\hline \multirow{10}{*}{ 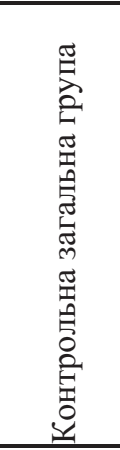 } & 1 & 30 & 55.7 & 16.7 & & & \\
\hline & 2 & 33 & 40.5 & 13.4 & & & \\
\hline & 3 & 35 & 57.1 & 19.9 & & & \\
\hline & 4 & 37 & 49.2 & 18.2 & & & \\
\hline & 5 & 40 & 60 & 24 & & & \\
\hline & 6 & 39 & 53.4 & 20.8 & & & \\
\hline & 7 & 41 & 51.4 & 20.9 & & & \\
\hline & 8 & 42 & 49.4 & 20.7 & & & \\
\hline & 9 & 32 & 57.2 & 18.3 & & & \\
\hline & 10 & 37 & 52.1 & 19.2 & & & \\
\hline \multicolumn{2}{|c|}{ Середнє у групі } & $36.6 \pm 4,03$ & $52.6 \pm 5,54$ & $19.21 \pm 2,85$ & & & \\
\hline
\end{tabular}


Ефект нокдауну у всіх паразитів починався 3 дезорієнтації, тобто кліщ починав рухатися в сторону, потім вниз та по колу. Час від моменту перетину паразитами нижньої межі ділянки, обробленого препаратами, до їх відпадання становило: $з$ тестом препарату ПрофіЛайн краплі протипаразитарні 0,50-3,54 хв, 3 тестом препарату ПрофіЛайн нашийник

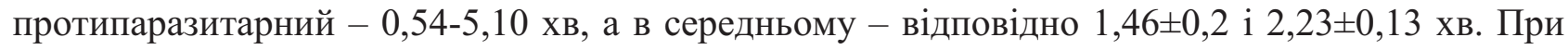
цьому максимальна висота підйому кліщів по тесту 3 діючою речовиною фіпроніл $+\mathrm{S}-$

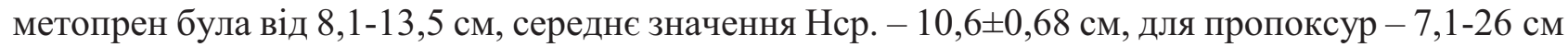
i $15,64 \pm 4,37 \mathrm{~cm}$.

Крім того, слід вказати що показник Т10 - час проходження кліщем обробленої

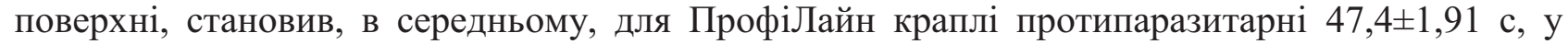
препарату ПрофіЛайн нашийник протипаразитарний - 40,03 44,53 с, в контрольній групі - до $36,6 \pm 4,03$ с. Час відпадання паразитів 3 контрольного тесту був більше 10 хв, при цьому висота підйому кліща по тесту була максимальною - до кінця стрічки.

Відпалих кліщів переносили в чистий посуд та спостерігали впродовж 1 години. Через 1 год встановили, що всі паразити з дослідних груп загинули, в той час як кліщі контрольної групи залишалися живими. Життєздатність кліщів перевіряли за їх рухливістю та реакцією на дихання.

\title{
В И С Н О В К И
}

1. Таким чином, препарат ПрофіЛайн краплі протипаразитарні має виражений нокдаунефект. Час настання стану нокдауну становить 1,46 хв при середній висоті підйому 10,6 $\pm 0,68$ см. Препарат ПрофіЛайн нашийник протипаразитарний також має виражений нокдаунефект. Час настання стану нокдауну становить 2,23 хв при середній висоті підйому 15,64 \pm 4,37 см. Різниця у результатах пов'язана з різними діючими речовинами та механізмами їх впливу, що і підтверджено у літературі щодо властивостей вище зазначених хімічних сполук.

2. Також слід зазначити, що різниці в результатах, щодо настання стану нокдаун у кліщів, у залежності від району міста, не виявлено.

Перспективи досліджень. Для розробки нових ефективних інсектоакарицидних препаратів необхідно знати як саме впливає діюча речовина на ектопаразитів. В подальшому плануємо продовжити дослідження інших діючих речовин та концентрацій для визначення їх нокдаун-ефекту.

\section{EXPLORING THE SPEED OF KNOCKDOWN STATE OCCURRENCE | THE HIGHT OF IXODID MITE CLIMB ON THE FABRIC PROCESSED WITH MEDICINES | PROFILINE ANTIPARASITIC DROPS AND PROFILINE ANTIPARASITIC COLLAR}

\author{
S. A. Sapko \\ LLC «SRE Suzirye» \\ 4, Zernova str., Kharkiv, 61105, Ukraine \\ S U M M A R Y
}

The speed of knockdown state occurrence, the height of ixodid mites climb on the fabric processed with ProfiLine antiparasitic drops and ProfiLine antiparasitic collar are determined. The composition of ProfiLine antiparasitic drops contains fipronil in combination with S-methoprene, in ProfiLine antiparasitic collar - propoxur. ProfiLine antiparasitic drops medicine is an insectoacaricide solution, which used in practical conditions one time by dot application on the animal skin. ProfiLine antiparasitic collar intends to permanent wearing by animal with the aim of prevention against ectoparasites. 
The effect of knockdown in all parasites was starting from disorientation, which means the mite started to move aside, then down and around. Time from the moment of crossing by parasites the lower border of site, processed by medicines, into their fall off, was amounted to: in test of ProfiLine antiparasitic drops - 0,50-3,54 minutes, in test of ProfiLine antiparasitic collar - 0,54-5,10 minutes, and in average - correspondently 1,46 and 2,23 minutes. Meanwhile the maximal height of mite climb in test with active ingredient fipronil+S-methoprene was from $8,1-13,5 \mathrm{~cm}$, an average value of AH 10,6 cm, for propoxur - 7,1-26 cm and 15,64 cm.

Besides it should be noted that average T10 value for ProfiLine antiparasitic drops was 47,4 sec, and ProfiLine antiparasitic collar - 40,03 sec, in control group - up to 36,6 sec.

The time of parasites fall off from controll test was over 10 minutes, meanwhile the height of mite climb by test been maximal - up to the end of tape.

The fall down mites were forwarded in clean utensils and observed during one hour. It was determined after the lapse of time, that all parasites from experimental group died, meanwhile the mites from controll group staying alive. The mites vitality was checking by their mobility and reaction to breath.

Thus, ProfiLine antiparasitic drops has an expressed knockdown effect. The time of knockdown state occurrence is 1,46 minutes, when the average height of climb $-10,6 \mathrm{~cm}$. ProfiLine antiparasitic collar has also an expressed knockdown effect, which is 2,23 minutes with the average height of climb 15,64 cm.

Keywords: PROFILINE ANTIPARASITIC DROPS, PROFILINE ANTIPARASITIC COLLAR, FIPRONIL, PROPOXUR, S-METHOPRENE, KNOCKDOWN EFFECT, MITES, INSECTOACARICIDE.

\title{
ИЗУЧЕНИЕ СКОРОСТИ НАСТУПЛЕНИЯ СОСТОЯНИЯ НОКДАУН, ВЫСОТА ПОДЬЕМА ИКСОДОВЫХ КЛЕЩЕЙ ПО ОБРАБОТАННОЙ ТКАНИ ПРЕПАРАТАМИ ПРОФИЛАЙН КАПЛИ ПРОТИВОПАРАЗИТАРНЫЕ И ПРОФИЛАЙН ОШЕЙНИК ПРОТИВОПАРАЗИТАРНЫЙ
}

\author{
C. А. Сапко \\ ООО «НПП «Сузирье» \\ ул. Зерновая, 4, Харьков, 61105, Украина
}

А Н Н О Т А ИЯ

\begin{abstract}
Определены скорость наступления состояния нокдауна, высота подъема клещей по обработанной ткани препаратами ПрофиЛайн капли противопаразитарные и ПрофиЛайн ошейник противопаразитарный. ПрофиЛайн капли противопаразитарные содержат в составе фипронил в сочетании с S-метопрен, ПрофиЛайн ошейник противопаразитарный - пропоксур. Препарат ПрофиЛайн капли противопаразитарные представляют собой инсектоакарицидный раствор, в практических условиях применяются однократно путем точечного нанесения на кожу животного. ПрофиЛайн ошейник противопаразитарный предназначен для постоянного ношения животным с целью профилактической защиты от эктопаразитов.

Установлено, что препараты, которые тестируются, имеют выраженный нокдаунэффект, время наступления состояния нокдауна составляет: в препарате ПрофиЛайн капли противопаразитарные 1,46 мин, ПрофиЛайн ошейник противопаразитарный - 2,23 мин при средней высоте подъема соответственно 10,6 и 15,64 см.

Ключевые слова: ПРОФИЛАЙН КАПЛИ ПРОТИВОПАРАЗИТАРНЫЕ, ПРОФИЛАЙН ОШЕЙНИК ПРОТИВОПАРАЗИТАРНЫЙ, ФИПРОНИЛ, ПРОПОКСУР, SМЕТОПРЕН, НОКДАУН-ЭФФЕКТ, КЛЕЩИ, ИНСЕКТОАКАРИЦИД.
\end{abstract}


1. Paliy A. P. Distribution of poultry ectoparasites in industrial farms, farms, and private plots with different rearing technologies / A. P. Paliy [et al.] // Biosystems Diversity. - 2018. - 26(2). - P. 153-159. DOI:10.15421/011824.

2. Davey R. B. Therapeutic and persistent efficacy of fipronil against Boophilus microplus (Acari: Ixodidae) on cattle / R. B. Davey [et al.] // Veterinary Parasitology, 1998. - V. 74, № 2-4. P. 261-276.

3. Sirisoma N. S. Fipronil-based photoaffinity probe for Drosophila and human beta 3 GABA receptors / N. S. Sirisoma [et al.] // Bioorganic \& Medicinal Chemistry Letters, 2001. - V. 11, № 22. - P. 2979-2981.

4. Возможности химии сегодня и завтра / Opportunities in Chemistry Today and Tomorrow: перевод с английского / Д. С. Пиментел, Д. А. Кунрод; под ред. Ю. Д. Третьяков // Москва : Мир, 1992. - 36 с.: ил.

5. Kovacic P. Propoxur: a novel mechanism for insecticidal action and toxicity. [Текст] / P Kovacic, R. Somanathan // Rev Environ Contam Toxicol. 2012. - 218:141-50. DOI: 10.1007/9781-4614-3137-4_4. Review. PubMed PMID: 22488607.

6. Мельников Н. Н. Пестициды. Химия, технология, применение [Текст] / Н. Н. Мельников // М.: Химия, 1987. - 154 с.

7.Арисов М. В. Методы определения эффективности инсектицидов, акарицидов, регуляторов развития и репеллентов при эктопаразитозах плотоядных животных [Текст] / М. В. Арисов, И. А. Архипов // Российский паразитологический журнал. 2018. - №1. URL: https://cyberleninka.ru/article/n/metody-opredeleniya-effektivnosti-insektitsidov-akaritsidovregulyatorov-razvitiya-i-repellentov-pri-ektoparazitozah-plotoyadnyh

8. Gazzavi-Rogozina L. Метод епізоотичної оцінки місцевості щодо іксодових кліщів. [Текст] / L.Gazzavi-Rogozina [та інші] // НВ ЛНУ ветеринарної медицини та біотехнологій. Серія: Ветеринарні науки, 20(83), 36-39. https://doi.org/10.15421/nvlvet8307

\section{References}

1. Paliy A.P., Mashkey A.M., Sumakova N.V., Paliy A.P. Distribution of poultry ectoparasites in industrial farms, farms, and private plots with different rearing technologies. Biosystems Diversity. 2018. 26(2). - P. 153-159. doi:10.15421/011824

2. Davey R.B., Ahrens E.H., George J.E., Hunter J.S., Jeannin P. Therapeutic and persistent efficacy of fipronil against Boophilus microplus (Acari: Ixodidae) on cattle. // Veterinary Parasitology, 1998. - V. 74, № 2-4. - P. 261-276.

3. Sirisoma N.S., Ratra G.S., Tomizawa M., Casida J.E. Fipronil-based photoaffinity probe for Drosophila and human beta 3 GABA receptors.// Bioorganic \& Medicinal Chemistry Letters, 2001. V. 11- № 22. - P. 2979-2981.

4.Pimentel J., Konrod J. Vozmozhnosti khimii segodnja I zavtra // Opportunity's chemistry today and tomorrow. M.: Mir. 1992, p. 36 (in Russian)

5. Kovacic P, Somanathan R. Propoxur: a novel mechanism for insecticidal action and toxicity. Rev Environ Contam Toxicol. 2012. 218:141-50. DOI: 10.1007/978-1-4614-3137-4_4. Review. PubMed PMID: 22488607

6. Melnikov H. H. Pesticides/ Chemistry, technology and application. M.: Chemistry, 1987. - p. 154. (in Russian)

7. Arisov M. V., Arkhipov I. A. Methods for determining the effectiveness of insecticides, acaricides, development regulators and repellents in ectoparasites of carnivorous animals // Russian parasitological journal. 2018. №1. URL: https://cyberleninka.ru/article/n/metody-opredeleniya- 
effektivnosti-insektitsidov-akaritsidov-regulyatorov-razvitiya-i-repellentov-pri-ektoparazitozahplotoyadnyh (in Russian)

8. Gazzavi-Rogozina L., Tkachov O., Filiptsova, O., Naboka, O., Burlaka, I., Dyomina, Y., \& Pidgaina, V. (2018). The method of epizootic evaluations of the facial skeleton and axial keys. $N V$ LNU veterinary medicine and biotechnology. Seriya: Veterinary Science, 2018. - 20(83), 36-39. DOI.org/10.15421/nvlvet8307. (in Ukraine)

Рецензент - А. П. Палій, д. вет. н., с. н. с. ННЦ «ІЕКВМ».

УДК 636.09:636.2

doi: $10.36359 /$ scivp.2019-20-2.17

\title{
АНТИМІКРОБНА АКТИВНІСТЬ ДАНОФЛОКСАЦИНУ, ЕФЕКТИВНІСТЬ ТА БЕЗПЕЧНІСТЬ НОВОГО АНТИМІКРОБНОГО ПРЕПАРАТУ НА ЙОГО ОСНОВІ ПРИ ЛІКУВАННІ ТЕЛЯТ, ХВОРИХ НА ГОСТРУ БАКТЕРІАЛЬНУ ІНФЕКЦЮЮ ДИХАЛЬНИХ ШЛЯХІВ
}

\author{
T. I. Стецько, канд. с.-г. наук, \\ I. Я. Кочюмбас, д-р вет. наук, професор, академік НААН, \\ В. П. Музика, д-р вет. наук, \\ Н. Е. Лісова, канд. с.-г. наук, \\ О. М. П'ятничко, канд. с-г. наук, \\ Л. Л. Островська, канд. вет. наук
}

Державний науково-дослідний контрольний інститут ветеринарних препаратів та кормових добавок, вул. Донецька, 11, м. Львів, 79019, Україна

У статті представлені результати вивчення чутливості бактерій-ізолятів, збудників гострої бактеріальної інфекиії дихальних шляхів у молодняка великої рогатої худоби, до фторхінолонового антибіотика «третього покоління» данофлоксачину. Так, мінімальна інгібуюча концентрачія данофлоксачину для ізолятів Staphylococcus aureus cтановила 0,32 \pm

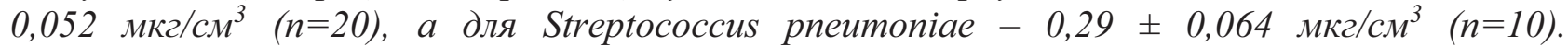
Застосування у терапевтичних дозах нового антимікробного препарату на основі данофлоксаиину Данофлокс 2,5\% (розчин для ін'єкиій) викликало клінічне одужання у телят, хворих на гостру бактеріальну інфекиію дихальних шляхів, щзо було підтверджено результатами загального аналізу крові хворих тварин після проведеної антибіотикотерапії. Дослідження імунологічних та біохімічних показників крові показали відсутність негативного впливу препарату на імунний захист та фізіолого-функиіональний стан організму молодняка великої рогатої худоби.

Ключові слова: ФТОРХІНОЛОНИ, ДАНОФЛОКСАЦИН, ВРХ, ТЕЛЯТА, РЕСПІРАТОРНІ ІНФЕКЦІЇ, ЧУТЛИВІСТЬ МІКРООРГАНІЗМІВ, ТЕРАПЕВТИЧНА ЕФЕКТИВНІСТЬ, БЕЗПЕЧНІСТЬ. 